\title{
PENGELOLAAN ZAKAT DALAM KAITANNYA DENGAN PENGENTASAN KEMISKINAN DI SULAWESI SELATAN DAN KALIMANTAN TIMUR
}

\section{Oleh : Muhammad As'ad}

\section{PENDAhUluan}

Agama Islam datang membawa ajaran, selain mengatur hak individual, juga mengatur hak hidup masyarakat. Suatu kenyataan dalam sejarah umat manusia, setiap masyarakat mengenal adanya Si Kaya dan si Miskin. Menghadapi kenyataan hidup ini dengan segala perbedaannya, Islam meletakkan kemiskinan sebagai salah satu problem masyarakat yang harus diatasi dalam rangka menjamin kemaslahatan dan martabat manusia.

Dalam rangka mengentaskan kemiskinan, Alquran menganjurkan banyak cara yang harus ditempuh, yang secara garis besar dapat dibagi pada tiga hal pokok : 1) kewajiban setiap individu yang tercermin dalam kewajiban berusaha, 2) kewajiban orang lain/masyarakat yang tercermin pada jaminan rumpun keluarga dan jaminan sosial dalam bentuk zakat dan shadaqah wajib, dan 3) kewajiban pemerintah untuk mencukupi kebutuhan setiap warga negara melalui sumber-sumber dana yang sah (lihat Shihab, 1996 b : 452-458).

Meskipun demikian, zakat bukanlah satu-satunya gambaran dari sistem yang ditampilkan oleh ajaran Islam, namun diakui bahwa zakat itu penting arti dan kedudukannya karena merupakan titik sentral dari sistem itu (lihat Yafie 1994 : 174). Para ulama mengakui zakat sebagai salah satu rukun Islam, namun pandangan mereka tentang penerapan ajaran zakat tidak selalu sama. Pemikiran tentang zakat mengalami perkembangan sejalan dengan perkembangan masyarakat.
Sudan menjadi tradisi bagi sebahagian umat Islam, termasuk di Sulawesi Selatan dan Kalimantan Timur, menyalurkan zakat, baik zakat fitrah maupun zakat Maal secara langsung kepada orang atau lembaga yang dipandang berhak menerimanya. Fenomena ini mencerminkan adanya kebebasan para muzakki dalam menyalurkan zakatnya.

Penyaluran zakat secara langsung kepada mustahiq, baik berupa perorangan atau lembaga, mempunyai segi-segi yang menguntungkan, tetapi tidak luput dari kelemahan-kelemahan. Keuntungannya antara lain : muzakki dapat melihat secara langsung manfaat zakat. Sebaliknya, cara tersebut dapat menyebabkan zakat tidak tersalurkan secara merata : pemanfaatannya secara terencana, terpadu dan terkontrol sulit dilakukan : dapat mendorong lahirnya lembaga penghimpun zakat yang tidak bertanggung jawab; dan sebagainya.

Zakat berpotensi untuk melepaskan umat dari penderitaan dan kemiskinan serta mengangkat harkat dan martabat manusia. Namun pengamatan sementara menunjukkan hasil-hasil nyata yang dibiayai dari zakat masih terbatas : penyalurannya cenderung bersifat karikatif tanpa upacara yang lebih produktif dan berkesinambungan. Keterbatasan pemanfaatan zakat erat kaitannya dengan sistem pengelolaan dan fungsionalisasi dari lembaga-lembaga pengelola zakat (amil zakat).

Pengorganisasian zakat diperlukan untuk memantapkan kepercayaan masyarakat, utamanya wajib zakat. Peranan pemerintah diperlukan dalam hal ini, di samping keikut sertaan pemimpin-pemimpin agama. Sistem 


\section{PENGELOLAAN ZAKAT DALAM KAITANNYA DENGAN PENGENTASAN KEMISKINAN DI SULAWESI SELATAN DAN KALIMANTAN TIMUR}

administrasi dan penyusunan personalia harus didasarkan pada prinsip-prinsip manajemen yang sehat agar pelaksanaan zakat dapat berjalan sebaik-baiknya (Ali, 1988 : 65 -66).

Kesadaran akan pentingnya pengorganisasian zakat dengan lembaga pengelola zakat yang permanen dan profesional semakin meningkat di kalangan ulama, cendekiawan muslim dan pemerintah. Kesadaran ini ditandai dengan pembentukan pengelola zakat yang dikenal dengan BAZIS (Badan Amil Zakat, Infaq dan Shadaqah). Lembaga zakat ini sudah terbentuk di berbagai daerah, baik Tingkat I maupun Tingkat II di Indonesia, termasuk di Sulawesi Selatan dan Kalimantan Timur.

BAZIS di Sulawesi Selatan dan Kalimantan Timur telah melakukan upaya-upaya pengelolaan zakat, namun belum mendapat respon secara maksimal dari kalangan pembayar zakat. Umat Islam di daerah ini masih banyak yang awam terhadap keberadaannya; penyaluran zakat, baik zakat fitrah maupun zakat Maal, masih banyak dilakukan secara tradisional yang telah diakrabi dalam jangka waktu yang lama, seperti lewat pengurus-pengurus mesjid (aparat syara') atau secara langsung kepada mustahiq.

Pada sisi lain, badan amil zakat masih banyak yang belum melakukan pengelolaan zakat secara profesional; dan zakat yang diberikan kepada mustahiq habis begitu saja tanpa dapat dinikmati secaraberkesinambungan. Hal ini terjadi karena pemberian zakat kepada mereka tidak diikuti dengan pembinaan. Asumsi tersebut mendorong perlunya penelusuran lebih jauh tentang pengelolaan zakat di Sulawesi Selatan dan Kalimantan Timur dalam upaya peningkatan tarap hidup dana kesejahteraan keluargakeluarga muslim.

Berkaitan dengan itu, ada tiga pertanyaan yang diangkat sebagai masalah penelitian, yaitu :

1. Berupa apa profil lembaga amil zakat di Sulawesi Selatan dan Kalimantan Timur. ?
2. Bagaimana sistem pengelolaan zakat yang dilakukan oleh lembaga amil zakat itu. ?

3. Bagaimana cara penggunaan zakat bagi penerima zakat. ?

Penelitian ini bertujuan untuk memperoleh jawaban-jawaban pertanyaan tersebut sehingga terbentuk suatu gambaran yang nyata tentang keberadaan badan/lembaga amil zakat dan sistem pengelolaan zakat, baik usaha pengumpulannya maupun pendistribusiannya kepada para mustahiq, termasuk usaha pembinaan mustahiq. Dengan demikian hasil penelitian ini diharapkan dapat berguna bagi berbagai pihak sebagai bahan masukan dalam rangka penyusunan program dan langkah-langkah kebijaksanaan pembinaan umat pada umumnya, dan pengelolaan zakat yang berdaya guna pada khususnya.

Penelitian ini dilakukan pada lima daerah di Sulawesi Selatan dan di Kalimantan Timur. Sasaran penelitian pada setiap daerah adalah badan/lembaga amil zakat dan infaq/shadaqah. Pemilihan kelima daerah penelitian ini didasarkan pada karakteristik masing-masing. Di Sulawesi Selatan dipilih Kotamadya Ujungpandang dan Kabupaten Sidenreng Rappang (Sidrap) : sedang di Kalimantan Timur ditetapkan Kotamadya Samarinda, Kotamadya Balikpapan, Kabupaten Kutai (Bontang).

Penelitian pada kelima daerah/sasaran penelitian merupakan kasuistik, bukan merupakan sampel penelitian yang bermuara pada suatu generalisasi. Namun demikian, dengan menggabarkan kelima kasus penelitian, sedikit banyaknya, dapat memberikan gambaran tentang pengelolaan zakat di Sulawesi Selatan dan Kalimantan Timur.

Oleh karena penelitian ini bersisfat kualitatif deskriptif maka teknik pengumpulan data yang dipergunakan adalah : 1. wawancara bebas dengan berbagai pihak yang terkait dengan penelitian, 2. observasi terhadap aktivitas lembaga/amil badan amil zakat serta kehidupan keagmaan masyarakat lingkungannya, terutama lingkungan kelompok 


\section{PENGELOLAAN ZAKAT DALAM KAITANNYA DENGAN PENGENTASAN KEMISKINAN DI SULAWESI SELATAN DAN KALIMANTAN TIMUR}

masyarakat penerima zakat, dan 3. studi dokumen dan kepustakaan, terutama yang berkaitan dengan lembaga/amil zakat yang diteliti. Data yang dikumpulkan merupakan data kualitatif, dikategorikan berdasarkan kerangka acuan, kemudian dianalisis secara deskriptif interpretatif.

\section{H. ZIS DAN KEMISIKINAN}

Zakat, infaq dan shadaqah (ZIS) adalah tiga istilah yang dipakai Alquran menyangkut pengeluaran harta benda yang dimiliki. Kata infaq juga dipakai untuk zakat, demikian pula kata shadaqah. Karena itu dalam penelitian ini diberikan batasan operasional masingmasing.

Zakat berarti sejumlah harta tertentu yang diwajibkan Allah diserahkan kepada orang-orang yang berhak (Qardawi 1991 : 34). orang yang diwajibkan berzakat dan yang menerima zakat hams memenuhi syaratsyarat tertentu (Hasan. 1996 : 1, Ali.1988 :26). Zakat yang dimaksud dalam penelitian ini adalah; Sejumlah harta terntetu yang dikeluarkan oleh seseorang sebagai pelaksanaan kewajiban dari Allah kepada pihak yang berhak menerimanya menurut ketentuan agama Islam.

Arti infaq dalam bentuk yang umum ialah mengorbankan harta pada jalan yang dapat menjamin segala kebutuhan manusia menurut tatacara yang diatur oleh hukum (Bably. 1989 : 77). Infaq dalam arti tersebut terbagi dua, yaitu : infaq yang diwajibkan oleh syara seperti zakat dan infaq yang disunahkan. Infaq sunah luas sekali dan tidak merapunyai batas ketentuan akan tetapi diserahkan kepada kaum muslimin (Bably. 1989 : 121 - 122). Menginfakkan harta adalah memberikan harta tanpa kompensasi. Apabila pemberian harta tersebut dengan suatu kompensasi maka tidak disebut infaq (Nabhani. 1996 : 215).

Shadaqah adalah pemberian sukarela yang dilakukan oleh seseorang kepada orang lain, terutama kepada orang-orang miskin, setiap kesempatan yang terbuka yang tidak ditentukan, baik jenis, jumlah maupun waktunya (Ali. 1988: 23). Pemberian ini dilakukan dengan mengharapkan keredhaan dan pahala dari Allah SWT dan tidak mengharapkan suatu imbalan jasa atau penggantian (Asri. 1996 : 19). Alquran dan Hadits memakai shadaqah baik untuk zakat maupun shadaqah biasa. Karena itu shadaqah dibagi dua, yaitu : shadaqah wajib (zakat) dan shadaqah biasa.

Penggunaan istilah infaq dan shadaqah dalam arti bukan zakat sering dipertukarkan karena batasannya tidak jelas. Taqiuddin An Nabhani memakai istiliah shadaqah (sedekah) sebagai bahagian dari infaq (Nabhani. 1996 : 215) : sementara Sarmuji Asri memakai istilah infaq bagi shadaqah sunah (Asri. 1996 : 20). Pada sisi lain, Muhammad Daud Ali membedakan shadaqah dari infaq berdasarkan penekanan pada pihak diberi, yaitu orang lain terutama orang-orang miskin (lihat Ali. 1988 : 23). Sehubungan dengan itu, istilah infaq dan shadaqah dalam tulisan ini keduanya dipakai dalam pengertian yang sama, dalam arti penggabungan kandungan pengertiannya. Infaq/shadaqah diberi batasan operasional untuk membedakannya dari zakat sebagai berikut : Sejumlah pemberian yang diberikan kepada pihak lain berdasarkan anjuran Allah tanpa imbalan jasa. Karena pemberian ini dasarnya anjuran Allah, bersifat sukarela dan tidak terbatas serta bertujuan untuk memperoleh pahala dan keredhaan Allah.

Zakat merupakan kewajiban dan termasuk salah satu rukun Islam. Zakat dua macam, yaitu : zakat maal dan zakat fitri. Zakat Maal berkaitan dengan harta kekayaan yang dimiliki seseorang, sedang zakat fitri bersifat individual dalam arti dibebankan kepada individu perkepala. Zakat merupakan ibadah yang berdimensi sosial. Fungsi dan kegunaannya bersifat ganda. Pada satu sisi, terhadap diri dan harta muzakki, dan pada sisi 


\section{PENGELOLAAN ZAKAT DALAM KAITANNYA DENGAN PENGENTASAN KEMISKINAN DI SULAWESI SELATAN DAN KALIMANTAN TIMUR}

lain terhadap masyarakat, utamanya penerima zakat muztahiq.

Dinamakan zakat karena di dalamnya terkandung harapan untuk beroleh berkah, membersihkan jiwa dan memupuknya dengan berbagai kebajikan (Sabiq. 1993 : 5). Ibnu Taimiyah berkata : "Jiwa orang yang berzakat itu menjadi bersih dan kekayaannya akan bersih pula : bersih dan bertambah maknanya (QARDAWI. 1991 : 35). Zakat mensucikan jiwa dari kekikiran dan kedosaan (AshShidiqy, $1991: 24)$.

Zakat dilihat dari sisi penerimanya, membebaskan manusia dari sesuatu yang menghinakan mar tab at mulia manusia dan merupakan kegiatan tolong-menolong yang sangat baik, dalam menghadapi problema kehidupan dan perkembangan zaman (Qardawi, 1991 : 867). Zakat diambil dari orang kaya diberikan kepada orang miskin yang dengannya mereka dapat memenuhi kebutuhan hidupnya berupa sandang, pangan, papan dan lainnya sehingga mereka mampu berperan dalam kehidupan, melaksanakan kewajibannya taat kepada Allah, zakat bagi sipenerima, juga akan membersihkannya dari sifat dengki dan benci. Hasad, kebencian dan kedengkian adalah penyakit yang akan menghacurkan keseimbangan pribadi, jasmani dan rohani ; keseimbangan masyarakat, material dan spiritual (lihat Qardawi. 1991 : 873 - 874).

Dalam Alquran (S. Attaubah : 60) Allah memerinci pihak-pihak yang berhak menerima zakat, yaitu orang-orang faqir, miskin, amil zakat, muallaf, memerdekakan budak, orang-orang yang berutang, untuk jalan Allah dan orang-orrang yang dalam perjalanan (Ibnu Sabil). Di antara kedelapan asnafy\&ng dikemukakan Alquran terdapat orang-orang yang membutuhkan jaminan sosial karena berada pada kondisi yang tidak menguntungkan, hidup dalam kepapaan, kebutuhan hidupnya tidak terpenuhi sebagaimana mestinya.

Zakat adalah salah satu jaminan sosial dalam Islam. Zakat sangat potensial untuk memenuhi kebutuhan hidup kaum papa yang berkekurangan jika pemungutannya dilakukan dengan sebaik-baiknya jumlahnya cukup besar. Zakat pada dasarnya bukan belas kasihan dari orang-orang kaya kepada orangorang yang berkekurangan karena memang hak mereka di tangan orang-orang kaya. Ini menunjukkan perhatian yang sangat besar terhadap problema kemiskinan.

Kemiskinan adalah salah satu penyakit masyarakat yang dapat menggoyahkan sendisendi kehidupan umat. Kemiskinan adalah ancaman yang serius bagi aqidah. Akibat ketimpangan sosial bisa timbul penyimpangan aqidah. Hampir-hampir kefaqiran membawa kepada kekafiran (H.R. Abu Nairn dari Anas). Selain itu, kemiskinan pun berbayaha terhadap ahlak dan moral. Kemelaratan dan kesengsaraan sering mendorong orang melakukan tindak pelanggaran, misalnya pencurian, perampokan dan pelacuran. Kemiskinan dapat pula membahayakan pemikiran. Orang tidak dapat berfikir jernih dalam keadaan lapar (lihat Qardawi. 1995 : 24-27). Banyak anak yang putus belajar karena faktor ketidakmampuan orang tuanya membiayai sekolahnya.

Kemiskinan merupakan ancaman terhadap keluarga, baik dalam segi pembentukan, kelangsungan, maupun keharmonisannya. Lebih jauh lagi, kemiskinan berbahaya terhadap keamanan dan kestabilan masyarakat. Selama di tengah masyarakat terdapat gubuk-gubuk kumuh di samping istana megah, rumah-rumah sederhana di samping gedung pencakar langit dan golongan yang berkekurangan di samping golongan yang memiliki kekayaan berlimpah, maka rasa dengki akan timbul. Dalam situasi ini, kelompok perusak akan mengambil kesempatan dengan memanfaatkan mereka yang terlilit kemiskinan (Qardawi, 1995 : 29-30).

Untuk memenuhi kebutuhan para faqir miskin, selain zakat sebagai kewajiban agama, juga inffaq/shadaqah sebagai bantuan 
PENGELOLAAN ZAKAT DALAM KAITANNYA DENGAN PENGENTASAN

KEMISKINAN DI SULAWESI SELATAN DAN KALIMANTAN TIMUR

sosial. Karena bantuan ini bersifat sukarela maka erat kaitannya dengan keinsafan pribadi. Menggantungkan penanggulangan problema kemiskinan semata-mata kepada sumbangan sukarela dan keinsafan pribadi, tidak dapat diandalkan. Teori ini telah dipraktekkan berabad-abad lamanya, namun hasilnya tidak pernah memuaskan (Shihab, 1996 b:454).

Sehubungan dengan itu, agar tanggung jawab keadilan sosial dapat terlaksana dengan baik diperlukan adanya penetapan hak dan kewajiban. Kewajiban zakat merupakan hak delapan asnaf yang telah ditetapkan (Q.S. Attaubbah : 60). Penetapan syariat zakat dapat melahirkan "paksaan" kepada yang berkewajiban melaksanakannya. Pemerintah dapat tampil memaksakan kewajiban tersebut untuk diserahkan kepada yang berhak (lihat Shihab, 1996 b : 455$)$.

Unsur paksaan dalam pengumpulan zakat terkesan dalam perintah Allah kepada Rasul-Nya : "petiklah zakat dari harta mereka yang dengannya engkau membersihkan dan mensucikan mereka" (Q.S. Attaubah : 103). Bahkan Rasul mengancam akan memungut secara paksa zakat pembangkang dengan tambahan berupa denda. Dalam suatu hadits disebutkan (Qardawi. 1991 : 79). Orang yang membayar zakat itu untuk memperoleh pahala maka ia pasti mendapatkan pahala itu, tetapi orang yang tidak membayarnya maka kita akan mengutip zakat itu beserta separuh kekayaannya. Ini merupakan ketentuan tegas dari Tiihan, dan keluarga Muhammad tidak boleh mengambil sedikitpun (H.R. Ahmad, Nasa'i dan Abu Daud). Bahkan bila pembangkangpembangkang zakat perlu kekerasan maka boleh diperangi/dibunuh. Rasulullah bersabda (Qardawi. 1991 :81). Saya diperintahkan untuk memerangi manusia sehingga mereka mengirarkan syahadat bahwa tidak ada Tuhan selain Allah dan Muhammad adalah Rasul-Nya, mendirikan shalat dan menunaikan zakat. Bila mereka sudah melaksanaka hal itu, maka darah mereka sudah memperoleh perlindungan dari saya, kecuali oleh karena hak-hak Islam lain, yang dalam hal ini perhitungannya diserahkan kepada Allah (H.R. Bukhari dan Muslim dari Abdullah bin Umar). Tindakan khalifah Abubakar ra. yang mendapat dukungan para sahabat memerangi pembangkangpembangkng zakat merupakan saksi sejarah.

\section{ffl. PROFIL BADAN PENGELOLA ZIS DI SULAWESI SELATAN DAN KALIMANTAN TIMUR}

Propinsi Sulawesi Selatan dan Propinsi Kalimantan Timur keduanya berada di pesisir selat Makassar secara bersebelahan. Sulawesi Selatan pada sebelah timurnya dan Kalimantan Timur pada sebelah baratnya. Sejak dahulu hubungan kedua daerah ini cukup lancar. Transportasi laut yang menghubungkan keduanya tergolong lancar sesuai dengan masanya. Perahu-perahu layar dan kapalkapal kayu bermotor pergi pulang menyeberangi Selat Makassar.

Transportasi laut ini mendukung kelancaran arus perekonomian antara kedua daerah ini. Perahu layar/kapal motor mengangkut beras dan hasil bumi lainnya dari Sulawesi Selatan ke Kalimantan Timur dan sebaliknya mengangkut kayu dan hasil hutan lainnya dari Kalimantan Timur ke Sulawesi Selatan. Hubungan ekonomi dan perdagangan ini menggugah semangat migrasi orang-orang dari Sulawesi Selatan sehingga di antaranya memutuskan untuk bertempat tinggal di Kalimantan Timur guna mencari penghidupan yang lebih layak.

Penduduk asli Sulawesi Selatan terbagi atas empat dtnik besar, yaitu Bugis, Makassar, Mandar dan Tana Toraja (Tator). Etnik Bugis, Makassar dan Mandar termasuk pemeluk agama Islam yagn fanatik; sedangkan etnik Tator kebanyakan pemeluk Kristen. 


\section{PENGELOLAAN ZAKAT DALAM KAITANNYA DENGAN PENGENTASAN \\ KEMISKINAN DI SULAWESI SELATAN DAN KALIMANTAN TIMUR}

Propinsi Kalimantan Timur secara garis besar dihuni oleh dua kelompok, yaitu : kelompok penduduk asli dan kelompok suku pendatang. Kelompok penduduk asli Kalimantan Timur, bahkan Kalimantan umumnya dikenal dengan suku Daya (dayak). Cikal bakal suku ini berasal dari Melayu, baik proto-Melayu maupun Dietro Melayu. Pada sisi lain, proto-Melayu (Melayu Tua) dikenal dengan Suku Dayak dan Dietro-Melayu (Melayu Muda) dikenal dengan suku-suku Bulungan, Berau, Bajau, Tidung dan Kutai.

Pada umumnya suku-suku Daya terbagi dalam enam kelompok besar, salah satu di antaranya yang mendiami daerah Kalimantan Timur, yaitu kelompok Kenyan, Kay an dan Behau. Wilayah Kabupaten Kutai, selain dihuni oleh kelompok Dayak tersebut, juga oleh kelompok Tunjung, Benua dan Bentian yang termasuk kelompok Ot-Danum dari Kalimantan Tengah (lihat Coomans, 1987 : $53)$.

Suku Dayak di Kalimantan Timur yang dikenal sekarang ini mendiami daerah pedalaman, sedang suku asli yang mendiami daerah-daerah perkotaan dikenal dengan suku Kutai. Banyak unsur kebudayaan lama dari Kutai sama dengan kebudayaan suku Daya. Demikian pula banyak orang Kutai berpendapat, bahwa pada masa lampau mereka termasuk suku Daya Tunjung. Kelompok orang Kutai mengalami pengaruh banyak sekali, terutama setelah mereka memeluk Islam sehingga menjadi indetitas etnik yang membedakannya dari suku Daya. Bahkan sampai akhir-akhir ini orang Daya yang masuk Islam disebut juga orang Halo (Kutai). Nama Daya diperuntukkan bagi semua penghuni di daerah pedalaman Kalimantan yang tidak beragama Islam (lihat Coomaans. 1987 : 2-4).

Suku-suku pendatang yang bermukim di Kalimantan Timur sekarang ini cukup banyak, dan yang menonjol adalah : Banjar, Bugis/Makassar dan Jawa/Sunda. Suku-suku ini tergolong penganut Islam yang baik, sehingga penduduk Kalimantan Timur, terutama di Kotamadya Samarinda, Kotamadya Balikpapan dan Kabupaten Kutai kebanyaka beragama Islam.

Masyarakat di Sulawesi Selatan dan Kalimantan Timur pada umumnya tergolong "masyarakat Islam". Sebagaimana pada umumnya masyarakat, di antara anggotaanggotanya ada yang tergolong orang-orang kaya, memiliki pendapatan melebihi kebutuhan pokokbya; dan di sampingnya ada orang-orang yang tergolong miskin, yang tidak memiliki sumber penghasilan atau memiliki tetapi tidak dapat memenuhi kebutuhan pokok minimalnya sebagaimana layaknya.

Untuk menjamin terciptanya kesejahteraan umum masyarakat diperluka uluran tangan si kaya untuk meringankan beban si miskin. Islam mengemukakan konsep zakat dan infaq/shadaqah sebagai media kepedulian sosial. Fenomena masyarakat menunjukkan zakat yang merupakan kewajiban tidak efektif manakala hanya diserahkan pada kesadaran para wajib zakat. Untuk itu diperlukan pengelola yang memiliki daya tekan selain daya profesional. Pelaksanaan zakat pada awal sejarahnya ditangani sendiri oleh Rasulullah saw. dengan mengirim para petugas untuk menarik zakat dari mereka yang ditetapkan sebagai pembayar zakat. Untuk melestarikan pelaksanaan seperti itu, Khalifah Abubaraira. Terpaksa mengambil tindakan keras karena adanya sementara pembangkang yang menolak menyerahkan zakatnya kepada petugas yang dikirim oleh khalifah. Baru pada zaman Khalifah Usmanlah diadakan suatu kelonggaran dengan membebaskan para pembayar zakat untuk melaksanakan penyerahan zakat kepada para penerima zakat, yaitu dalam dua jenis zakat : zakat logam mulia dan zakat perniagaan (Yafie, 1994 : 233-234).

Sepanjang sejarah umat Islam di Indonesia belum pernah terjadi pengelolaan zakat ditangani langsung oleh pemerintah, 
meskipun pemerintah tetap peduli padanya. Gagasan untuk ditetapkan suatu undangundang mengenai zakat sampai saat ini belura dapat menjadi kenyataan. Meskipun demikian, tidaklah berarti bahwa umat Islam di Indonesia mengabaikan sama sekali syariat zakat ini. Pendistribusian zakat kebanyakan bersifat tradisional, diserahkan kepada panitia masjid/aparat syara' atau ulama yang selanjutnya diserahkan kepada yang berhak, ataukah diserahkan secara langsung kepada yang dinilainya berhak. Pelaksanaan zakat demikian bersifat temporer, yaitu pada bulan Ramadhan.

, Pada era Orde Baru perhatian pemerintah terhadap pengelolaan zakat meningkat. Hal ini disebabkan semakin disadarinya potensi zakat yang cukup besar bila dikelola secara baik karena dapat berdaya guna dan berhasil guna. Pada peringatan Isra' Mi'raj Nabi Muhammad saw. di Istana Negara pada tanggal 26 Oktober 1968 Presiden Suharto dalam pidatonya mengharapkan zakat dikembangkan secara efesien dengan cara-cara yang lebih luas dan dengan pengarahan yang tepat. Pada waktu itu Presiden Suharto secara pribadi menyatakan dirinya bersedia menjadi amil zakat.

Tidak lama sesudah itu, pada tanggal 5 Desember 1968 di DKI Jakarta dibentuk amil zakat berdasarkan SK Gubernur. Langkah ini kemudian diikuti beberapa pemda Tk. I lainnya. Badan amil Zakat, Infaq dan Shadaqah (BAZIS) Propinsi Sulawesi Selatan terbentuk pada tanggal 3 Februari 1986 dengan nama Yayasan Bazis Sulawesi Selatan berdasarkan akte pendirian yang ditanda tangani oleh Notaris Hasan Zaini Zainal. Pada tahun 1986 ini juga BAZIS Propinsi Kalimantan Timur terbentuk berdasarkan SK Gubernur Nomor 81 Tahun 1986. Baik di Sulawesi Selatan maupun di Kalimantan Timur pembentukan BAZIS diprakarsai oleh para ulama dan tokoh-tokoh masyarakat yang berperanan dalam birokrasi pemerintahan.

Pemerintah Daerah Kotamadya Ujungpandang, bagaikan menyambut bola yang bergulir, membentuk BAZIS Kotamadya Ujungpandang pada tahun 1986 dengan Walikotamadya Ujungpandang sebagai Ketua
Umum dan Kabag Kesra sebagai Ketua Pelaksana Harian. Dalam kepengurusan dilibatkan unsur Majelis Ulama, cendekiawan muslim dan unsur dari pemerintah daerah sendiri. Meskipun demikian pengeloaan zakat didominasi oleh pemerintah daerah, dalam hal ini Ketua Umum dan Ketua Pelaksana Harian. Dominasi ini dimaksudkan agar pengelolaan zakat lebih efektif dan efesien karena menggunakan jalur birokrasi.

Keterlibatan Departemen Agama Kotamadya Ujungpandang secara instansional tidak tercermin dalam kepengurusan BAZIS Ujungpandang. Hal ini menyebabkan hubungan Departemen Agama Ujungpandang dengan BAZIS Ujungpandang hanya bersifat horizontal.

Kepengurusan BAZIS Ujungpandang pada sisi personil telah merekrut person sesuai SK Bersama Mendagri dan Menag Nomor 29 tahun 1991 dan Nomor 47 tahun 1991 sebagaimana tercantum: "Kepengurusan BAZIS dapat terdiri dari unsur ulama, cendekiawan dan tokoh masyarakat formal dan non formal yang beragama Islam, baik sebagai pembina maupun sebagai pelaksana" (Bab IV P.7). Namun dari sisi struktur organisasi belum sejalan dengan SK tersebut. SK bersama itu (Bab I P. 1) menunjuk adanya kerjasama secara instansional antara pemerintah daerah dengan Departemen Agama setingkat. Pembinaan umum seharusnya dilakukan oleh Kepala Kantor Departemen Agama Kotamadya.

Selain di Kotamadya Ujungpandang, diberbagai kabupaten juga sudah terbentuk BAZIS tingkat kabupaten, seperti di Kabupaten Sidenreng Rappang (Sidrap). BAZIS Sidrap telah terbentuk sebelum tahun 1994 dengan keterlibatan Pemerintah Daerah yang cukup menonjol. Berdasarkan SK Bupati Sidrap No. 50/11/1994 tanggal 11 Pebruari 1994 diadakan penyempurnaan struktur kelembagaan dan mekanisme tata kerja dengan mengacu pada SK Bersama Mendagri dan Menag. 


\section{PENGELOLAAN ZAKAT DALAM KATTANNYA DENGAN PENGENTASAN KEMISKINAN DI SULAWESI SELATAN DAN KALIMANTAN TIMUR}

Meskipun dalam SK Bersama tersebut jelas dinyatakan bahwa BAZIS adalah lembaga swadaya masyarakat (Bab I P. 1), namun keterlibatan pemerintah secara instansional cukup besar karena pembinaan umum dan pembinaan teknis berada di tangannya (Bab I P. 1 (b \& c).

Struktur kepengurusan BAZIS Sidrap terdiri atas :

1. Badan Pembina : Ketua Umum, Wakil Ketua ( 2 orang), Sekretaris dan Wakil Sekretaris

2. Pelaksanaan harian : Ketua dan Wakil ketua serta sekertaris dan wakis sekertaris.

3. Bidang-bidang : Perencanaan dan Pengembangan, pedayagunaan, pengumpulan/motivasi, keuangan, dan tatausaha.

4. Pembantu, terdiri atas sembilan orang.

Personalia kepengurusan BAZIS Sidrap mencerminkan keterpaduan antara tokohtokoh agama dan tokoh-tokoh masyarakat sebagaimana yang diharapkan dalam SK bersama (Bab IV P. 1 (1). Sebagai ketua umum badan pembina ialah Bupati Sidrap dan wakil ketua Badan Pembina Kakandep Agama Sidrap.

Keterpaduan demikian juga terlihat pada BAZIS Kalimantan Timur. Personalia Kepengurusannya juga berasal dari tokoh Agama (ulama) dan tokoh masyarakat, baik yang duduk dalam pemerintahan maupun yang tidak. Hal ini mencerminkan eksistensi BAZIS sebagai lembaga swadaya milik umat, bukan milik golongan tertentu. Selain itu, juga dimaksudkan untuk memudahkan koordinasi urusan dan sekaligus menjembatani kepentingan dan kebijakan yang diberlakukan.

Struktur kepengurusan BAZIS Kalimantan Timur terdiri atas :

1. Pelindung

2. Dewan Pembina (7 orang)

3. Pengurus Harian : Ketua, wakil ketua (5 orang), sekretaris (4 orang dan bendahara (2 orang).
4. Bagian-Bagian : Pengumpulan, pendayagunaan, litbang, motivasi dan penyuluhan, serta sekretariat.

Dalam kepengurusan BAZIS Kalimantan Timur sebagai pelindung ialah Gubernur Kalimantan Timur dan sebagai dewan Pembina Kakanwil Deparetemen Agama Kalimantan Timur dan Ketua MUI Kaliman$\tan$ Timur.

Meskipunjumlah personil kepengurusan cukup banyak tetapi kebanyakan mereka tidak aktif setiap hari di kantor BAZIS. Kehadiran mereka hanya sewaktuwaktu. Yang aktif setiap hari adalah para tenaga sekretariat yang berjumlah 8 orang (semuanya pensiunan). Mereka memperoleh gaji bulanan berasal dari APBD Kalimantan Timur, bukan dari dana ZIS.

Kebijakan BAZIS Kalimantan Timur lahir dari suatu musyawarah/rapat di tingkat lembaga. Semua kebijakan diputuskan secara bersama-sama, namun persoalan teknis operasional tidak dibicarakan lagi di tingkat pengurus akan tetapi ditangani langsung oleh ketua atau orang yang ditugaskan. Hal ini mengakibatkan terbukanya peluang pelencengan prosedure, khususnya di bidangn administrasi, seperti halnya kerjasama BAZIS Kalimantan Timur dengan ICMI Orwil Kalimantan Timur mengenai penyaluran dana ZIS pada Baitul Maal Wattamwil (BMT) tanpa agremen.

Di Propinsi Kalimantan Timur banyak perusahaan negara (BUMN) yang beroperasi dengan merekrut karyawan yang jumlahnya cukup besar, seperti pertamina dan PT. Pupuk Kalimantan Timur. Pertamina DAK Balikpapan mempekerjakan karyawan dengan jumlah besar, kebanyakan mereka beragama Islam. Pendapatan para karyawan tergolong relatif tinggi sehingga rata-rata hidupnya berkecukupan. Kondisi ini sangat potensial dalam hal dana ZIS.

Pada mulanya dana ZIS dari para karwayan pertamina DAK Balikpapan tidak terkordinir dengan baik, sehingga tidak 


\section{PENGELOLAAN ZAKAT DALAM KAITANNYA DENGAN PENGENTASAN}

KEMISKINAN DI SULAWESI SELATAN DAN KALIMANTAN TIMUR

berdaya guna dan berhasil guna secara optimal dalam ratigka peningkatan kesejahteraan umat. Kenyataan inimenjadi salah satu pendorong dibentuknya BAZIS pertamina DAK Balikpapan pada tanggal 7 Agustus 1993.

Sebelum terbentuknya BAZIS Pertaminan DAK Balikpapan, di Pertamina pusat terbentuk BAZIS berdasarkan SK Pengurus Korpri Pertamina tertanggal 10 Pebruari 1992. Dalam tubuh Korpri pertamina, baik di pusat maupun di daerah-daerah terbentuk Badan Da'wan Islam (BDI). Pada suatu kesempatan BDI pertamina pusat mengundang ketua dan sekretaris BDI dari daerah-daerah untuk mengadakan pertemuan. Dalam pertemuan itu para pengurus BDI daerah diarahkan dan dimotivasi untuk membentuk BAZIS di daerah masing-masing. Setelah itu terbentuklah BAZIS dalam lingkungan BDI di berbagai daerah, termasuk di pertamina DAK Balikpapan.

Periode kepengurusan BAZIS Pertamina DAK Balikpapan hanya satu tahun. Pada awal berdirinya diangkat berdasarkan SK PUD KAL No. 137/C000/93/b7 tanggal 7 Agustus 1993, dan selanjutnya kepengurusan setiap tahun diangkat berdasarkan SK BDI pertamina DAK Balikpapan. Meskipun priode kepengurusan hanya satu tahun, namun person yang ditunjuk sebagai pengurus setiap tahun tidak harus orang baru.

Struktur organisasi BAZIS pertamina DAK Balikpapan terdiri atas : Ketua umum dibantu oleh 3 orang wakil ketua dengan bagian tugas masing-masing, yaitu bagian operasi, bagian perencanaan, dan bagian keuangan. Selain ketua, ditunjuk beberapa orang sekretaris, bahkan ada personil yang khusus menangani administrasi keuangan. Sebagai bagian dari kepengurusan ini dibentuk tiga bidang, yaitu : bidang peribadatan, bidang sosial dan bidang pendidikan. Ketiga bidang ini merupakan pelaksana operasional pendistribusian dan pendayagunaan dana ZIS yang terkumpul.

No. 14 Th. IX Juli/Desembet 1997
Aktivitas operasional BAZIS Pertamina DAK Balikpapan berpusat pada sebuah kantor yang permanen dalam kompleks Pertamina Kelurahan Prapatan, Kecamatan Balikpapan Timur. Yang bertugas secara rutin untuk mengelola administrasi di kantor ini ialah seorang pelaksana harian BAZIS yang memperoleh gaji dari BDI pertamina DAK Balikpapan. Untuk kelancaran roda kegitan, setiap minggu diadakan pertemuan rutine pengurus, yaitu setiap Selasa malam sehabis shalat Isya.

Kalau di pertamina terbentuk BDI dibawa naungan Korpri maka di PT. Pupuk Kalimantan Timur (PKT) yang berlokasi di Bontang ada Badan Pembina Umat Islam (BPUI) yang didirikan sejak tahun 1989. BPUI Korpri PKT menangani beberapa bidang, salah satu di antaranya adalah Baitul Maal yang dibentuk pada tanggal 1 Maret 1993. Baitul Maal belum berbuat banyak penanganannya dialihkan dari BPUI ke Yayasan Baiturrahman yang dinyatakan berdiri pada tanggal 7 Desember 1992 dengan Akte Notaris tertanggal 20 April 1993.

Yayasan Baiturrahman mengkordinir sejumlah sebelas bidang yang berstatus otonom, di antaranya : Ta'mir, pendidikan, progaram anak asuh (PAA), baitul maal, dan baituttamwil. Yang mengelola zakat ialah Baitul Maal Baiturrahman, sedangkan infaq/shadaqah dari para karyawan PKT kebanyakan disalurkan lewat PAA dan Ta'mir.

Struktur kepengurusan Baitul Maal Baiturrahman terdiri atas :

1. Forum Musyawarah

2. Badan Pemeriksa dan Pengarah

3. Pengurus Harian : Ketua dan wakil ketua, sekretaris dan wakil sekretaris, serta bendahara dan wakil bendahara.

Di bawa pengurus ini dibentuk dua divisi yang masing-masing ditangani oleh seorang ketua divisi dengan bidang masingmasing, yaitu : 
a. Divisi mustahiq membidangi:

1) survey dan pendataan,

2) evaluasi dan distribusi,

3) pembinaan dan pelatihan.

b. Divisi muzakki membidangi :

1) informasi dan pendataan,

2) penyuluhan,

3) investasi dan pengembangannya.

Forum musyawarah yang beranggotakan para muzakki dan pengurus Yayasan Baiturrahman merupakan forum tertinggi. Pengurus BaituI Maal dipilih oleh forum ini dan kepadanya dipertanggung jawabkan kegiatan pengurus setiap tahunnya lewat suatu rapat terbukan. Selain itu dalam rapat forum musyawarah ini ditetapkan rencana kerja periode setahun berikutnya.

\section{PENGUMPULAN DAN PENDISTRIBUSIAN ZIS}

\section{A. Pengumpulan ZIS}

BAZIS Tingkat I Sulawesi Selatan telah menetapkan pola pengumpulan ZIS dengan sistem kordinatif, terutama dalam pengumpulan ZIS di Kotamadya Ujungpandang sebegai ibukota propinsi. Dengan membuka rekening pada Bank Pembangunan Daerah (BPD) ZIS yang terkumpul disimpan di Bank yang selanjutnya disalurkan, baik langsung kepada mustahiq maupun lewat BAZIS Ujungpandang. Dana ZIS yang berasal dari Kotamadya Ujungpandang, demikian pula dari kabupaten/kotamadya lainnya dikembalikan $80 \%$ untuk didistribusikan oleh BAZIS daerah kotamadya/kabupaten, dan $20 \%$ sisanya dikelola oleh BAZIS Sulawesi Selatan.

Sasaran ZIS yang dikelola oleh BAZIS di Sulawesi Selatan adalah : 1. infaq/zakat calon jamaah haji, 2. infaq pegawai/karyawan yang beragama Isla, 3. infaq anggota ABRI yang beragama Islam, 4. infaq rumah tangga muslim (RTM), dan
5. infaq/zakat usahawan muslim. Dari kellima sumber ZIS tersebut, yang menonjol pemasukannya selama ini adalah infaq/zakat calon jemaah haji.

Cara pengumpulan dana ZIS selama ini melalui jaringan pemda, yaitu camat dan lurah/kepala desa dengan cara instruksi, terutama infaq RTM dan usahawan muslim; sedangkan infaq pegawai negeri pemungutannya lewat pengurus Korpri unit-unit dan sub-sub unit; dan infaq/zakat calon jemaah haji melalui penyelenggaraan urusan haji.

Umat Islam di Ujungpandang sangat potensial dari segi ZIS, jika terkelola dengan baik; selain karena jumlah penduduknya yang beragama Islam cukup besar, juga sudah cukup banyak yang tergolong muzakki, baik dari usahawan musllim maupun tenaga profesional, termasuk para pegawai yang berpenghasilan relatif tinggi. Akan tetapi dana ZIS yang terkumpul masih kecil jumlahnya, dan jumlah yang kecil ini kebanyakan berasal dari calon jemaah haji. Sebagai gambaran pada medio Januari - Juni 1996 jumlah dana yang terkumpul Rp 310.769.100,- berasal dari calon jemaah haji, pegawai negeri, RTM dan usahawan muslim. Diakui bahwa dana ZIS yang paling banyak dan bersifat kontineu setiap tahun adalah dari calon jemaah haji. Setiap calon jemaah haji di Ujungpandang dipungut dana berkisar Rp 300.000,- sampai 350.000 perorang.

Terbatasnya dana ZIS yang berhasil dikumpulkan oleh BAZIS Ujungpandang disebabkan karena masyarakat Islam belum mengenal dan memahami secara baik sehingga banyak pihak yang menyalurkan secara langsung Z1S-nya kepada mustahiq, baik berupa kelembagaan seperti panitia mesjid dan pondok pesantren, maupun perorangan (faqir/miskin). BAZIS Ujungpandang belum melakukan usaha yang cukup berarti untuk mensosi- 


\section{PENGELOLAAN ZAKAT DALAM KAITANNYA DENGAN PENGENTASAN KEMISKINAN DI SULAWESI SELATAN DAN KALIMANTAN TIMUR}

alisasikan zakat, memberikan motivasi dan menyadafkan masyarakat pentingnya ZIS. Di samping itu transparansi manajemen belum terlaksana secara umum.

Melihat sumber yang selama ini merupakan andalan BAZIS Ujungpandang, hampir dikatakan zakat yang merupakan kewajiban belum banyak tersentuh. Apakah para calon jemaah haji yang merupakan sumber utama selama ini menyerahkan dananya dengan kesadaran berzakat, ataukah karena memandang sebagai aturan yang telah ditetapkan ? Hal ini masih perlu diskusi dan pengkajian tersendiri.

BAZIS Kabupaten Sidenreng Rappang tidak jauh beda dengan BAZIS Ujungpandang dari segi usaha pengumpulan ZIS. Sumber dana yang menjadi lahan garapannya juga adalah calon jemaah haji, pegawai.negeri, RTM dan usahawan muslim. BAZIS Sidrap belum menggarap lahan yang subur di daerah pertanian, yaitu para petard, terutama petani pemilik dan punggawa tani yang sangat potential sebgai daerah lumbung padi.

Zakat sebagai sumber dana umat yang sangat potensial belum tergarap dengan baik di Sidrap; zakat usahwan muslim yang terkumpul masih sangat sedikit. Sebagai gambaran, pada tahun 1995 dana ZIS yang terkumpul sebesar Rp 223.170.500,- yang bersumber dari calon jemaah haji sebesar Rp 210.789.500,- (94,5\%) dan berasal dari usahawan muslim hanya Rp 679.500,- (0,3\%). Selebihnya, dari pegawai negeri sipil Rp 9.986.200,$(4,5 \%)$ dan RTM Rp 1.715.300,$(0,8 \%)$. Dana dari usahawan muslim meningkat sebesar $63,6 \%$ dari tahun 1994 yang hanya berjumlah Rp 247.500,-

Namun demikian, BAZIS Sidrap, sudah mulai melakukan terobosan- terobosan untuk menggugah kesadaran berzakat bagi umat Islam, hal ini ditandai dengan penerbitan khutbah seragam berbahasa Bugis sekali sebulan dengan tema/materi masalah zakat; selain itu penyebaran brosur yang berisikan dasar hukum dan kewajiban zakat, barangbarang yang dizakati, sasaran/pendayagunaan zakat, dan perincian/tabel zakat.

Faktor yang berkaitan dengan rendahnya penyaluran ZIS lewat BAZIS, terutama berkaitan dengan pemahaman masyarakat terhadapnya masih sangat terbatas, hal ini berkaitan dengan masalah informasi dan keterbukaan managemen. Faktor lain adalah pemahaman masyarakat terhadap kewajiban zakat, khususnya bila dikaitkan dengan pajak, hal ini memerlukan petunjuk dan fatwa yang dapat dipahami oleh masyarakat secara umum.

Beda dengan BAZIS di Kalimantan Timur, calon jemaah haji bukan merupakan sumber ZIS. Fokus perhatiannya tetap pada sumber zakat dan infaq/shadaqah. Pada mulanya infaq yang dikelola adalah dari pengawai negeri dan BUMN yang beragama Islam, selain jajaran Departemen Agama. Pada saat itu pihak Departemen Agama telah mencanangkan "gerakan seribu rupiah" pada setiap bulan Ramadhan dan BAZIS ikut mendukung dan menyukseskan.

Sejak tahun 1991 usaha peningkatan pengumpulan ZIS dilakukan secara serius. Pertama dilakukan gerakan penyebaran informasi tentang hal-hal yang berhubungan dengan ZIS. Informasi ZIS disebarluaskan melalui ceramah agama, khutbah Jum'at dan media cetak, baik dalam bentuk koran, majalah/bulletin maupun dalam bentuk brosur. Bahkan BAZIS Kalimantan Timur sendiri menerbitkan majalah BAZIS yang secara khusus memberitakan informasi tentang pengelolaan ZIS. Gerakahan informasi ini sedikit 
PENGELOLAAN ZAKAT DALAM KAITANNYA DENGAN PENGENTASAN

KEMISKINAN DI SULAWESI SELATAN DAN KALIMANTAN TIMUR

banyaknya berpengarah pada umat Islam di Kalimantan Timur dalam memberi motivasi dan menggugah kesadaran tentang ZIS.

Berbarengan dengan gerakan informasi ini, selanjutnya dilakukan aktivitas operasional pengumpulan ZIS lewat kupon infaq. BAZIS menerbifkan 3 jenis kupon infaq, yaitu : seri K I bernilai Rp 300,- per lembar, seri K II bernilai Rp 500,- per lembar, dan seri K III tidak ditentukan nilainya (bersifat terbuka). Seri K III ini diperuntukkan kepada orang-orang yang dinilai mampu dari segi ekonomi. Penyebaran kupon-kupon infaq ini lewat 2 jalur, yaitu : jalur instansi bagi pegawai negeri/BUMN dan jalur lurah/kepala desa bagi non pegawai. Kegiatan pengumpulan dana lewat kupon infaq ini diperkuat oleh surat himbauan dari Gubernur KDH Tk. I Kalimantan Timur, terutama bagi pegawai lewat pemotongan gaji, masing-masing : gol. I \& II Rp 300,- dan Gol. Ill \& IV Rp 500,-. Usaha kupon infaq ini belum mencapai sasaran yang diharapkan karena berbagai kendala, baik dari pengumpul maupun dari kesadaran masyarakat.

Kegiatan pengumpulan zakat maal mulai dilakukan secara intensif oleh BAZIS Kalimantan Timur pada tahun 1992/1993, terutama di bulan Ramadhan. Salah satu cara ditempuh adalah mengajak para aqniya dan para pejabat teras daerah menyerahkan zakatntya lewat BAZIS. Usaha ini memperlihatkan hasil yang menggembirakan; jumlah pembayar zakat, baik dari pejabat pemerintah maupun agniya lainnya, dan jumlah dana zakat yang terkumpul grafiknya semakin naik.

Adapun zakat Fitri, selama ini BAZIS Kalimantan Timur belum melakukan kordinasi pengelolaannya. Hal ini karena pertimbangan kehati-hatian dengan menyadari masih kuatnya mengakar pemahaman bahwa zakat fitri harus sampai di tangan mustahiq selambatlambatnya selesai pelaksanaan shalat Idul Fitri. Menyadari besarnya jumlah zakat fitri ini dan selama ini manfaatnya hanya bersifat konsumtif dan kurang menyentuh kebutuhan umat secara mendasar, yaitu meningkatkan kesejahteraan hidup, maka BAZIS Kalimantan Timur merencanakan akan mengelola zakat fitri mulai bulan Ramadhan tahun $1417 \mathrm{H}$.

Telah dikemukakan, bahwa di lingkungan pertamina DAK Balikpapan Kalimantan Timur juga terbentuk BAZIS, khusus untuk mengelola ZIS para karyawannya. Langkah awal yang dilakukan pada bulan Agustus 1993 ialah menggugah dan memantapkan kesadaran berZIS para karyawan lewat ceramah agama dan khutbah-khutbah Jum'at. Setelah berlangsung sekitar sebulan usaha mensosialisasikan ZIS di kalangan karwayan, BAZIS memulai langkah praktis dengan membuat surat edaran kepada karyawan meminta kesediannya mengeluarkan ZIS melalui pemotongan gaji.

Atas dukungan para pemimpin dan pejabat eselon, BAZIS pertamina DAK Balikpapan menggugah para karyawan untuk menyatakan kesediaannya ber-ZIS. Para pejabat eselon berusaha menyadarkan bawah-annya lewat bimbingan, dialog dan usaha lainnya. Usaha-usaha tersebut cukup berhasil, sebagaimana terlihat pada tahun 1993/1994 jumlah orang yang mengeluarkan Z1S-nya mencapai 1.794 orang. Jumlah ini mengalami peningkatan pada tahun 1994/1995 mencapai 3000 orang, kemudian menurun drastis pada tahun 1995/1996 menjadi 2.700 orang. Penurunan ini bukan dikarenakan menurunnya kesadaran ber-ZIS tetapi karena SK No. 09 dengan mempercepat masa pensiun di samping adanya pemindahan karyawan. Dana ZIS setiap bulannya mencapai rata-rata $\mathrm{Rp} 20$ juta. Dana ini diamankan sementara dengan membuka 


\section{PENGELOLAAN ZAKAT DALAM KAITANNYA DENGAN PENGENTASAN KEMISKINAN DI SULAWESI SELATAN DAN KALIMANTAN TIMUR}

rekening di Bank Dagang Negara Cabang Balikpapan.

Di lingkungan PT. Pupuk Kalimantan Timur Bontang juga dilakukan upayaupaya menyadarkan karyawan untuk mengeluarkan Z1S-nya. Seminar zakat yang berlangsung di Bontang atas prakarsa PT. Badak memegang peranan penting dalam menggugah kesadaran berzakat di Bontang, termasuk di lingkungan PKT. Seminar ini dihadiri antara lain : DR. M. Amin Rais, DR. Quraish Shihab, DR. A. M.Saifuddin dan Dr. Peunoh Dalih (Baiturrahman. 1993 : 6).

- Para pengurus BPUI Korpri PKT memandang problema zakat yang memerlukan pemecahan adalah pembaharuan pemahaman dalam berbagai aspeknya. Untuk pemecahan problema itu BPUI mendatangkan pakar-pakar untuk memberikan penjelasan/uraian yang kontemporer mengenai zakat. KH. Athiah Ali M. Da'i, MA adalah pakar yang paling banyak berperan. Berkali-kali ia tampil di lingkungan PKT memberikan ulasanulasan segar berkaitan dengan zakat. Tafsiran-tafsirannya tentang zakat dinilai baru dan sesuai dengan perkembangan zaman dengan mempertimbangkan hukum-hukum ekonomi.

Sebagai tindak lanjut berupa upaya riel, pada tanggal 5 Februari 1992 BPUI PKT mengeluarkan surat himbauan dan tuntunan berzakat disertai formulir program zakat. Sejak saat itu mulai terealisir program zakat maal dengan baik. Seiring meningkatnya kesadaran berzakat di kalangan karyawan PKT terasa perlunya badan yang permanen dan profesional, sehingga terbentuklah baiatal maal.

Pada bulan Ramadhan 1413 H. meskipun baital maal sudah terbentuk namun belum berfungsi sehingga pengumpulan ZIS termasuk fidyah masih seperti tahuntahun sebelumnya, di tangani oleh panitia zakat BPUI PKT yang bertugas pada setiap masjid di lingkungan PKT. Dana yang terkumpul sebanyak Rp 47.621.700, - ditambah beras sebanyak $410,5 \mathrm{~kg}$. Dana tersebut berupa zakat maal sebanyak Rp 24.994.000,- dan selebihnya dari zakat fitri, infaq/shadaqah dan fidyah.

Baital maal pada periode I April 1993 s.d Maret 1944 telah berhasil mengumpulkan zakat sebesar Rp 146.629.175,pada periode II April 1994 s.d. Maret 1995 naik menjadi Rp 172.000.622,- dan pada periode III April 1995 s.d. Maret 1996 meningkat menjadi Rp 242.941.219,-. Dana ini berasal dari zakat maal berupa : gaji karyawan, peransang produksi dan penjualan (PP\&P), bantuan cuti, bonus, dan perorangan/panitia. Jumlah muzakki juga mengalami peningkatan setiap tahunnya, sebagai gambaran, periode I sebanyak 788 orang, periode II naik menjadi 920 orang dan periode III bertambah menjadi 951 orang.

Peningkatan yang terjadi ini tidak terlepas dari upaya-upaya baital maal, dalam hal ini divisi muzakki, antara lain berupa : penyuluhan-penyuluhan dari nara sumber, membentuk perwakilanperwakilan muzakki per unit kerja, penyebaran informasi lewat bulletin dan pelayanan lain yang membantu para muzakki dalam menghitung zakatnya.

Baital maal ini hanya mengumpulkan zakat maal para karyawan PKT, baik lewat pemotongan pendapatan maupun penyerahan langsung dari muzakki. Adapun zakat fitri masih dikelola secaa tradisional pada keempat masjid yang ada di lingkungan PKT setiap bulan ramadhan dan langsung diserahkan kepada mustahiq pada saat itu.

B. Pendistribusian ZIS

Menurut ketentuan agama, dana ZIS yang terkumpul harus didistribusikan kepada para mustahiq sebagaimana dikemukakan dalam Alquran (S. Attaubah : 60). BAZIS Sulawesi Selatan menjabarkan sasasran prioritas sebagai berikut : 1. masjid/mushalla, 2. sarana pendidikan, 3. guru-guru mengaji, 4. faqir/miskin, 


\section{PENGELOLAAN ZAKAT DALAM KAITANNYA DENGAN PENGENTASAN KEMISKINAN DI SULAWESI SELATAN DAN KALIMANTAN TIMUR}

5. imam/aparat syara', 6. pengadaan Alquran, 7. pengadaan tikar sembahyang, 8. bantuan persertifikatan tanah-tanah wakaf, 9. bantuan perpustakaan masjid, 10. bantuan pembinaan organisasi ORPEHA dan LPTQ serta penyelenggarraan MTQ, dan 11. biaya orientasi da'i/muballig ZIS, pengadaan mobiler dan amil.

BAZIS Ujungpandang mendistribusikan ZIS serupa yang dilakukan BAZIS Sulawesi Selatan. Penyaluran ZIS pada tahun 1996 berupa : 1. bantuan kepada 156 masjid, masing-masing Rp 500.000,2. bantuan kepada 100 orang guru mengaji, masing-msing Rp 100.000,-, 3 . bantuan kepada 782 orang ekonomi lemah, masing-masing Rp 100.000,- dan 4. bantuan kepada 7 lembaga pendidikan Islam (Pesantren Rp 750.000,- dan madrasah Rp 300.000,- sampai Rp 400.000).

Pada umumnya penerima dana ZIS memanfaatkannya untuk hal-hal yang bersifat konsumtif. Penerima ZIS yang berupa lembaga memanfatkan untuk kelengkapan lembaganya, sedang penerima ZIS perorangan memanfaatkan untuk kebutuhan hidup sehari-hari. Tidak diperoleh data penerima ZIS di Ujungpandang dari ekonomi lemah yang menjadikan dana ZIS sebagai modal usaha yang dikembangkan. Hal ini berkaitan dengan minimnya dana ZIS yang diterima serta belum dilakukannya pembinaan secara berlanjut dari BAZIS.

BAZIS Sidenreng Rappang juga melakukan distribusi zakat tidak jauh beda dengan BAZIS Ujungpandang, yaitu kepada masjid/mushalla, lembaga pendidikan, pengajian dasar Alquran/guruguru mengaji, dan ekonomi lemah. Selain itu, BAZIS Sidrap juga memanfaatkan dana ZIS untuk pengadaan kitab suci Alquran yang disebarkan kepada masyarakat Islam lewat masjid dan lainnya.

Biaya pengelolaan ZIS di Sidrap, terutama pengumpulannya, ditanggung oleh dana ZIS, baik biaya penerangan/motivasi, biaya operasional pengurus dana biaya para pengumpul/kolektor. Yang melakukan pengumpulan ZIS adalah
camat/KUA kecamatan dan bendaharawan instansi-instansi. Mereka mendapat $10 \%$ dari dana yang dikumpulkan.

Pihak-pihak yang telah menerima zakat nampaknya tidak terinfentarisir dengan baik dalam rangka pemerataan. Akibatnya ada pihak yang telah memperoleh ZIS lebih dari satu kali, bahkan berkali-kali, sementara masih ada pihak lain yang belum mendapatkannya. Pada sisi lain, penyaluran ZIS terkadang tidak langsung kepada penerima, tetapi lewat perangkat kecamatan, sehingga dana itu terkadang tidak sampai secara keseluruhan, tetapi disunat $10 \%$ untuk keperluan lain.

Pada dasarnya penyaluran dana ZIS bagi BAZIS Kalimantan Timur secara prosedural, mulai dari penerimaan calon penerima ZIS, seleksi dari tim pendayagunaan ZIS dan penyalurannya kepada calon hasil seleksi. Waktu penyalurannya bersifat periodik. Dana ZIS yang disalurkan ada produktif dan ada yang konsumtif, yang konsumtif seperti 1) untuk kegiatan pendidikan, da'wah dan sejenisnya, 2) Untuk rehabilitasi sarana ibadah, dan pendidikan, 3) Bantuan Studi, bea siswa dan penelitian. Sedang yang produktif, yaitu 1) pinjaman modal usaha tanpa bunga kepada pengusaha kecil, 2) bantuan modal kerja berupa pemberian sarana/alat dan 3) menunjang pinjaman modal berupa simpanan kepada BPR syariah dan BMT.

Pinjaman modal kepada BPR dan BMT dimaksudkan untuk membantu operasionalisasi kegiatan kedua lembaga tersebut. Hingga tahun 1996 BAZIS Kalimantan Timur telah meminjamkan dana kepada kedua lembaga keuarigan tersebut sebesar Rp 100 juta. Agar bantuan/peny aluran produktif terbina dengan baik, mulai tahun 1996 BAZIS Kalimantan Timur akan menyerahkan pengelolaaonya kepada BMT.

Penerima ZIS yang melalui seleksi yang ketat berasal dari permohonan bea siswa, bantuan penelitian, bantuan modal usaha, bantuan pembangunan/rehabilitasi dan bantuan bagi organsasi Islam. Sedang para fakir miskin, anak yatim piatu daa 


\section{PENGELOLAAN ZAKAT DALAM KAITANNYA DENGAN PENGENTASAN}

KEMISKINAN DI SULAWESI SELATAN DAN KALIMANTAN TIMUR

muallaf, sebagai prioritas utama diberikan santunan sekaligus tanpa ada permohonan tertulis yang bersangkutan. Begitu pula bantuan kemahusiaan kepada warga yang mengalami bencana alam.

BAZIS BDI Pertamina DAK Balikpapan menyalurkan ZIS pada tiga bidang utama, yaitu peribadatan, pendidikan, dan sosial. Bantuan peribadatan diberikan kepada masjid/mushalla berupa material/bahan bangunan secara bertahap sesuai kebutuhan, setelah diadakan peninjauan dan seleksi berdasarkan skala prioritas. Termasuk dalam bidang peribadatan ini menyediakan dan mengirim secara periodik pada da'i ke daerah transmigran dan sekitarnya. Para da'i ini diberikan honor tetap perbulan sebanyak Rp 150.000 ,-

Penyaluran dana ZIS dibidang pendidikan meliputi bantuan pembangunan gedung TPA/TKA, honor guru dan santunan imam masjid, serta bea siswa kepada murid/siswa SD, SLTP, SLTA, dan Mahasiswa Perguruan Tinggi. Bea siswa diberikan perbulan dengan jumlah yang bervariasi sesuai tingkatan pendidikan, yaitu SD Rp 24.000,- perbulan dan peruguruan tinggi Rp 80.000,- perbulan. Pembinaan bagi para pernerima bea siswa dilakukan lewat masjid-masjid tertentu dari BAZIS Pertamnia dan dari pengurus masjid. Penerima bea siswa yang tidak dapat dibina lewat penerangan agama dan peringatan baik lewat pengurus masjid maupun oleh Pengurus BAZIS akan disetop bea siswanya.

Penyaluran dana ZIS di bidang sosial yaitu 1) sumbangan kepada pondok pesantren/panti asuhan berupa beras, modal usaha dan lainnya, 2) tambahan honor kepada 11 orang imam masjid di kompleks perumahan pertamina Balikpapan sebesar Rp 150.000,-/bulan, 3) bantuan pinjaman modal tanpa bunga kepada ekonomi lemah (pedagang kaki lima), dan 4) santunan kepada fakir miskin berupa paket ramadhan dan bantuan pengobatan. Bantuan pengobatan dapat berupa pengiriman pasien tertentu ke rumah sakit untuk perawatan dan penyediaan klinik Ibnu Sinaa. Para fakir miskin, anak yatim serta janda yang tidak mampu diberikan pengobatan di klinik secara cuma-cuma.

Pengusaha lemah menerima pinjaman modal untuk mengembangkan usahanya. Mereka dituntut mengembelikan pinjamannya secara menyicil setiap bulan. Waktu/tempat penyerahan cicilah ialah Jun'at pertama setiap bulan di masjid Istiqamah. Pada waktu itu mereka mendapatkan pembinaan keagamaan dan pengarahan usaha lewat pengajian yang dilanjutkan dengan dialog/diskusi.

Penyaluran dana ZIS di Baital maal Yayasan Baiturrahman PKT ditangani oleh divisi mustahiq. Sebagaimana telah dikemukakan, dalam divisi ini terdapat 3 bidang, yaitu : survey dan pendataan, eveluasi dan distribusi, serta pembinaan dan pelatihan mustahiq. Prinsip yang dianut dalam penyaluran zakat ialah : tepat, efektif dan bermanfaat. Untuk itu dalam penyaluran zakat terlebih dahulu dilakukan survay terhadap obyekobyek (mustahiq).

Informasi tentang mustahiq diperoleh dengan duajalur, yaitu : surat-surat permohonan yang masuk dan penemuan para surveyor. Pendataan terhadap mustahiq yang ditemukan para surveyor langsung dilakukan oleh surveyor itu, sedang survey dan pendataan terhadap mustahiq lewat permohonan dilakukan dengan dua cara yaitu : 1. yang berlokasi di Bontang dan sekitarnya dilakukan pendataan lapangan, dan 2. yang berlokasi di luarnya didata dengan sistem referensi. Obyek/mustahiq yaitu ada berupa perorangan dan ada yang bersifast lembaga/yayasan.

Hasil survey dan pendataan digunakan sebagai dasar pertimbangan untuk memutuskan layak tidaknya obyek itu untuk diberikan zakat; dan kalau layak, berapa besarnya dan dalam bentuk apa yang paling tepat. Zakat yang didistribusikan disesuaikan dengan kebutuhan, baik berupa uang maupun berupa material. Berupa uang, misalnya ; modal usaha, pelunasan utang, biaya pengobatan, biaya da'wah dan bea siswa. Berupa material, misalnya : bahan makanan, peralatan shalat, bahan bangunan dan pakaian sekolah. 


\section{PENGELOLAAN ZAKAT DALAM KAITANNYA DENGAN PENGENTASAN KEMISKINAN DI SULAWESI SELATAN DAN KALIMANTAN TIMUR}

\begin{abstract}
Penerimaan zakat yang berada di sekitar Bontang diundang untuk datang di sekretariat untuk menerima langsung zakat yang didistribusikan kepadanya, sedang yang berada di luarnya ditransfer lewat bank. Penyaluran zakat dilakukan pada setiap bulan dan jumlah muzakki setiap bulannya berfluktuasi. Jumlah zakat yang didistribusikan dan jumlah penerima zakat mengalami peningkatan setiap tahunnya, sejalan dengan peningkatan zakat yang diterima baitul maal. Sebagai gambaran dikemukakan bahwa pada periode 1993/1994 jumlah mustahiq 161 dengan zakat senilai Rp 91.595.500,pada periode 1994/1995 meningkat menjadi 296 mustahiq dengan zakat senilai Rp 138.200.550, - dan pada periode $1995 / 1996$ meningkat lagi menjadi 400 mustahiq dengan zakat senilai Rp 248.101.653.

Pembinaan dan pelatihan mustahiq disesuaikan dengan kondisi yang bersangkutan, baik berupa peningkatan pemahaman ajar an Islam maupun peningkatan wawasan pengetahuan dan keterampilan. Peningkatan pemahaman agama dilakukan lewat pengajian-pengajian dan penyuluhan yang dilakukan suverveyor. Peningkatan pengetahuan antara lain : mengikutkannya pada pelatihan-pelatihan, kursus-kr'rsus atau di perguruan tinggi.
\end{abstract}

\section{KESIMPULAN DAN SARAN}

Zakat adalah konsep yang dikemukakan oleh Islam sebagai antisipasi terhadap kenyataan sosial dalam setiap masyarakat demi terpeliharanya martabat hidup umat manusia. Konsep ini sangat ideal dan memuat nilainilai luhur kemanusiaan yang bila diaktualisasikan dapat menjamin kesejahteraan hidup masyarakat. Karena itu upaya-upaya mengaktualisasikannya perlu dilakukan secara terprogram dan dengan managerial yang baik.

Penerapan zakat di Sulawesi Selatan dan Kalimantan Timur sebagai syariat Islam telah berjalan melampau berbagai periode dan masa, tetapi sampai sekarang belum mencapai sasaran yang paling mendasar sebagai tujuan utama disyariatkannya, yaitu mengangkat taraf hidup masyarakat lemah. Hal ini berkatian dengan berbagai aspek, terutama kesadaran muzakki dan managemen kelambagaan zakat. Kesadaran muzakki dapat digugah dengan upaya sosialisasi yang baik dan managemen kelembagaan yang terbuka,

Zakat Fitri di Sulawesi Selatan dan Kalimantan Timur masih dikelola secara tradisional, baik lewat amil yang kurang terkordinir dan bersifat temporer maupun penyerahan langsung kepada mustahiq yang tidak merata. Kemanfaatannya bagi penerima zakat hanya mampu memenuhi kebutuhan sesaat. Agar zakat fitri ini berdaya guna dan berhasil guna perlu pengelolaan yang baik oleh lembaga zakat yang permanen.

Zakat maal yang secara teoritis sangat potensial, pengelolaannya di Sulawesi Selatan dan Kalimantan Timur masih terbatas : dari segi jumlah wajib zakat yang menunaikan zakatnya, besarnya penerimaan zakat, dan pendayagunaan zakat bagi para mustahiq. Kesadaran berzakat di kalangan umat Islam dapat digugah dengan terbentuknya lembaga/badan pengelola zakat yang permanen dan profesional dengan managerial yang tinggi, memiliki keterbukaan, keterpercayaan, kreativitas dan daya tekan/daya dorong yang tinggi.

Kombinasi tekanan dari atas dan dorongan dari bawah memiliki daya yang tinggi menggerakkan potensi zakat di kalangan umat. Keterlibatan pemimpin agama secara aktif dan pemimpin formal secara instansional dengan norma dan aturan yang berkekuatan hukum sangat menentukan keberhasilan pengelolaan zakat. Keteladanan dan panutan masih relevan dalam mensosialisasikan syariat zakat. 
PENGELOLAAN ZAKAT DALAM KAITANNYA DENGAN PENGENTASAN

$\underline{\text { KEMISKINAN DI SULAWESI SELATAN DAN KALIMANTAN TIMUR }}$

\section{KEPUSTAKAAN}

Ali, Muhammad Daud. 1988, Sistem Ekonomi Islam : Zakat dan Wakaf. Jakarta petama. Jakarta : Penerbit Universitas Indonesia (U1-Press).

Ash-Shddieqy, Muhammad Hasbi, Tengku, 1991. Pedoman Zakat. Cetakanke-7. Jakarta : PT. Bulan Bintang.

Asri, Sarmuji, 1996. Khotbah Jum'at : Tolong Menolong dalam Berbuat Kebaikan dan Taqwa. Dalam : Majalan Bulanan Khotbah Jum'at. No. 138. Jakarta : Ikatan Mawjid Indonesia.

Bably, Muhammad Mahmud, DR. 1989. Kedudukan Harta Menurut Pandangan Islam. Cetakan pertama. Jakarta : Penerbit Kalam Mulia.

Coomans, Mikhail. 1987. Manusia Daya: Dahulu, Sekarang, Masa Depart. Cet. 1. Jakarta : Penerbit PT. Gramedia.

Hasan, M. Ali. 1996. Masail Fiqhiyah : Zakat, Pajak, Asuransi dan Lembaga Keuangan. Ed. I. Cet. I. Jakarta : PT. Raja Grafmdo Persada.

Nabhani, Taqiuddin An-1996. Membangun Sistem Ekonomi Alternatif: Per-spektif Islam. Cetakan pertama. Surabaya : penerbit Risalah Gusti.

Permono, Syechul Hadi, DR. KH. SH.MA. 1992. Pendayagunaan Zakat dalam Rangka Pembangunan Nasional, Persamaan dan Perbedaan dengan Pajak. Jakarta : Pustaka Firdaus.

Proyek Pembinaan Zakat dan Wakaf 1993. Keputusan Bersama Menteri Dalam Negeridan Menteri Agama RItentang Pembinaan BAZIS dan Petunjuk Pelaksanaannya.
Qardawi, Yusuf, DR. 1991. Hukum Zakat : Studi Komparatif Mengenai Status dan Filsafat Zakat Berdasarkan Qur'an dan Hadis. Cetakan kedua, Bogor : PT. Pustaka Litera Antar Nusa.

1995. Kiat Islam Mengentaskan Kemiskinan. Cetakan ke-1. Jakarta : Gema Insani Press.

Sabin, Sayyid. 1993. Fiqih Sunnah. Jilid 3 Ceet. 8. Bandung : PT. Al Ma'arif.

Shihab, M. Quraish, DR. MA., 1996 a. Membumikan Alquran : Fungsi dan Peran Wahyu dalam Kehidupdn Masyarakat. Cetakan XII. Bandung : Penerbit Mizan.

1996 b. Wawasan Alquran : Tafsir Maudhu 'i atas Pelbagai Persoalan JJmat. Cetakan III. Bandung : Penerbit Mizan.

Yafie, Ali, KH. 1994. Menggagas Fiqhi Sosial: Dari Soal Lingkungan Hidup, Asuransi hingga Ukhuwah. cetakan III Bandung : Penerbit Mizan. 